\title{
LA BICICLETA DEL PANADERO DE JUAN CARLOS MESTRE: UNA LECTURA DESDE "AQUI"
}

\section{MARIO RODRÍGUEZ FERNÁNDEZ ${ }^{1}$}

$\mathrm{E}$ STE TeXTo MaYor De Juan Carlos Mestre (2012) se sitúa en el corazón mismo de la poesía española del siglo XXI. Más de 400 páginas que oscilan entre imágenes alucinantes ("un martillo es un hermetismo en mangas de camisa), el delirio ("y las monjas embarazadas con la información divina me ofrecían un puesto en su fábrica”) y referencias irónicas a la realidad más cotidiana ("donde la cobardía y las gabardinas abarrotan los percheros cuando caen dos gotas"). La oscilación se reproduce en la lengua, mejor dicho, anida en una lengua oscilante entre construcciones verbales que obedecen a una lógica creadora cercana al dadaísmo ("irte a robar gallinas entre los escombros del público") y dichos irónicos que pertenecen a la gramática del lenguaje de todos los días ("él me miró como no quiere la cosa").

La oscilación de la lengua produce lo que podría llamar un borronamiento entre la alta cultura (Rilke, Hölderin, etc.) y su antónimo la cultura popular, presente desde el título mismo del poemario: La bicicleta del panadero. El deslizamiento verbal afecta toda la construcción del texto, desde la contaminación genérica entre verso y prosa, hasta la coexistencia de modernísimos versículos lineales con la recuperación de formas vanguardistas del año 20 como los caligramas. Estrictamente lo que predomina en el texto

${ }^{1}$ Profesor de Literatura Chilena y Latinoamericana. Facultad de Humanidades y Arte, Universidad de Concepción. Concepción, Chile. E-mail: mariorod@udec.cl 
es el dialoguismo, diálogo entre verso y prosa, diálogo entre dos culturas, diálogo entre la tradición y la ruptura y, especialmente, diálogo entre dos lenguas: una que funciona como una "lengua extranjera dentro de la propia lengua" y otra habitual, enraizada en el habla cotidiana. No se trata de un bilingüismo, sino de dos formas de funcionamiento del español, marcadamente distintas, al punto que su uso simultáneo produce fuertes roces que hacen saltar chispas del lenguaje.

El "Poema uno", del cual provienen las citas anteriores, es un ejemplo del recurso dialógico cuyos desencuentros hacen saltar las chispas discursivas. Transcribo su comienzo:

le dije las sillas se hacen insoportables cuando están vacías sobre todo me dijo después de los entierros sobre todo después de los casamientos cuando se van los invitados tienes razón le dije un martillo es un hermetismo en mangas de camisa que entra en la sala de lectura dando voces dispuesto a abrir lo que sea no es para tanto dijo él ningún libro abre lo suficiente la boca como para enredarse en una investigación policial no te creas le dije yo se han dado casos en francia y al sur de la polonia ocupada ya pero no aquí dijo él donde la cobardía y las gabardinas abarrotan los percheros en cuanto caen dos gotas (Mestre, 2012: 9).

El sujeto que inicialmente toma la palabra, anuncia una experiencia general, que el segundo hablante se encarga de contextualizar, de traer a tierra firme. Si las sillas se hacen insoportables por su vacío, lo son dolorosamente más después de acontecimientos personales. El doble mecanismo de expresión de la subjetividad, que va desde lo general a lo más particularizado, es otra expresión configuradora de la lengua oscilante: "le dije las sillas se hacen insoportables cuando están vacías" (la experiencia generalizada), "sobre todo me dijo después de los entierros, después de los casamientos cuando se van los invitados" (la experiencia contextualizada). La construcción y expresión dual de la subjetividad corresponde a un allá y un aquí, dualidad que espacializa el texto. Éste se mueve entre dos espacios: el de allá donde se expresan las experiencias colectivas y el aquí donde predominan las personales. Lo más relevante es que en el primer espacio la lengua extranjera -declarada por el propio poeta: "hablo una lengua extranjera plagada de mosquitos que transmiten malaria" ("Las recompensas", p. 312)- se regodea consigo misma a tal punto que se transforma en un "neobarroco paródico", producto de una acumulación vertiginosa de imágenes heterogéneas: "No hay casa grande para la madre del olvido que desatiende / los geranios bajo la leche que hierve y las jóvenes nieblas / que se quedan a conversar 
tras la polvareda de / la resurrección" ("Los tejedores", p. 453). La imagen que arma el fragmento es la de "la madre del olvido", que podríamos incluir en un código tradicional (a menos que la leamos irónicamente), en oposición a las imágenes que se desprenden de ella, muy cercanas al rupturismo dadaísta: "los geranios bajo la leche que hierve" y las jóvenes nieblas que se quedan a conversar tras la polvareda de la resurrección". La última cláusula - "la polvareda de la resurrección"- señala el doble código en que debe leerse La bicicleta del panadero: el de la gravedad trascendente -el acontecimiento de la resurrección- y el paródico la "polvareda" que produce. El vacío, la pérdida que amenazan constantemente al universo poético de Mestre se ven contrarrestados por la ironía y el humor, a veces empleados con desparpajo, como el de que la resurrección ha levantado mucho polvo.

En el espacio del "acá", el de la experiencia cotidiana, la lengua se instala definitivamente en el decir más próximo al habla de todos los días:

\section{KAFKARRABIAS}

Sabes que nunca me ha gustado el fútbol

Y me regalas dos entradas para el final de la Copa de Europa

De sobra sabes que detesto a los novelistas de éxito

Y me llenas la casa de espantapájaros y papel servilleta

Mira que te dije que no se lo dijeras a nadie

Y a todos les has contado por quién doblan las campanas

Sabes que los caballeros me ponen las crines de punta

Y pones a todo volumen la caballería rusticana

No es que pongas a ciencia cierta lo sabes

Tengo serias dificultades para regatear al contrario

E invitas a mi cumpleaños a todos tus amantes jugadores de rugby

Tienes razón soy un quisquilloso aguafiestas, un kafkarrabias

Que besa en el descansillo con la Virgen de los Desamparados

(Mestre, 2012: 446).

Tal vez por mis lecturas de poetas chilenos que emplean una "lengua situada" en los términos de Enrique Lihn (sustituyo poesía por lengua) en la que la dicción poética española es considerada como una tradición verbal excesivamente recargada, como que hay demasiadas palabras, me encanta este texto y sus similares en el libro de Mestre, porque no hay "regodeos" lingüísticos ni saturación de imágenes, sino que funciona una lengua poética descarnada, llena de humor y sobreentendidos, aunque por debajo esté la incomodidad del sujeto incapaz de establecer relaciones positivamente amables con su contexto social y personal. 
El verso "Y a todos les has contado por quién doblan las campanas" está lleno de humor, ironía y doble sentido, tal como lo es el título del poema, Kafkarrabias. Lengua simplificada que vibra intensamente y hace un contacto inmediato, un clic con el lector. Pero no todo es críticamente risueño en el texto. El verso final introduce esa dimensión negativa del sujeto, en este caso el desamparo, que late expresivamente en las condiciones mismas en que se produce el flujo de la escritura de La bicicleta del panadero: "que se besa en el descansillo con la Virgen de los Desamparados".

Como ya es una suerte de lugar común de la crítica, la escritura de los grandes textos poéticos se sitúan en un "entre", en el espacio del entre: ni de allá ni de aquí, ni en la desgracia ni en la risa, ni en la prosa ni en el verso o en uno de los polos de la oposición de la lengua, inhabitual o cotidiana, sino en un tercer lugar que no debe entenderse como mezcla, o síntesis, sino como en un flujo que corre por el medio, como la corriente de agua que se desliza entre las dos riberas y va tocando simultáneamente a la una y a la otra.

Bajo el imperio de esta imagen movible y dinámica, propongo que geográficamente en una suerte de cartografía de la poesía de Mestre, ella se encuentra a medio camino entre Europa y América, entre Villafranca del Bierzo y Concepción. Es una poesía Atlántica y Pacífica que está tocando constantemente ambos bordes continentales.

Creo que la estadía de Mestre en Chile, ya lo he dicho anteriormente, ha sido fundamental en el desarrollo de su poesía. La poesía chilena, especialmente la de Parra, se transformó en un cable a tierra, del que carecían los primeros libros de Mestre: La visita de Safo (1983), Antífona del otoño en el valle del Bierzo (1985). Cable a tierra que se llama imaginación materialista, hibridismo, lengua poética que trabaja con el deshecho y no con el decorativismo verbal, lengua poética que habla de un pueblo que no existe y al que hay que inventarlo. Por eso el cable a tierra se llama también pueblo, no en el sentido políticamente vulgar, sino en el de la presencia de una enunciación colectiva de un pueblo menor, a veces bastardo, con lo que quiero decir que no es una poesía atrapada en problemas personales, desconectados de los colectivos, sino instalada en las experiencias profundas e intensas de un pueblo oprimido que resiste a todo lo que lo aprisiona. Ello significa que cuando afirmo que la poesía de Mestre se pone a delirar, no estoy hablando de un delirio individual, que puede ser fruto de una enfermedad, sino de uno continental, de un delirio de razas y pueblos que resisten el poder y se aferran a la utopía. Delirios de españoles, de judíos, de moros y chilenos.

En La bicicleta del panadero están las voces chilenas de Parra: "Podrías 
haberme hecho perro callejero o director de una sucursal / bancaria / Podrías haber hecho que me nombrasen director de la Biblioteca / Nacional" ("La sastrería", p. 456), "chao pescao" ("Agujero negro para Rojas"); "De alguna manera me considero un hombre afortunado / subido al andamio, campeón de los solos, pendiente de un hilo" ("Biografía”, p. 253); “Tener mala letra es el primer síntoma de inteligencia" ("Los viernes de la cacharrería", p. 277). Estas voces sujetan la imaginación estupenda de Mestre, sus desbordamientos, sus delirios, sus peligrosos acercamientos al mal: "Llevo cincuenta años columpiándome cabeza sobre el vacío" ("Ya, ya", p. 445). La ironía de esas voces, insertas en el propio título del poema, "Ya, ya", algo así como ya está bueno de repetir tantas advertencias, se despliega totalmente en el enunciado final del texto: "y nada por aquí, nada por allá, este soneto ha terminado". Evidente resistencia proporcionada por el humor, a la desgracia, al vacío que acecha, a través de la utilización cómicamente impropia de llamar soneto a una composición que evidentemente no lo es.

Hay resistencia principalmente a los poderes de la muerte y a la estética del mal, dentro del arrasamiento que hace Mestre de todos los poderes, poniéndolos patas para arriba, jugando irónicamente o muerto de la risa con ellos, como ocurre de forma insuperable en el poema "Árbol genealógico":

Aunque no lo parezcan son ellos encaramados al árbol genealógico. Llevan implícito un carácter de aquí te espero. No han descubierto América ni pintado un cuadro de Rothko. Pero él es don Adán y ella la señora Eva y eso no hay quien se lo quite. Para mi gusto un poco obsesionados por hacer del Paraíso un camino de flores. Se les ve saludables. Se nota que habitan el pasado del mundo. Según todos los cómputos han sido los primeros en dedicarse a la estética y a los simbolismos sagrados. La Belleza con mayúsculas y la epifanía del vacío. Quién iba a pensar que terminarían como terminaron, aquello de la perdiz, la tentación, la ciruela (Mestre, 2012: 428).

En el texto descubro un procedimiento notable con el que consigue Mestre producir el humor: el detalle léxico que transforma la semántica del poema. Desde el comienzo, el verbo encaramar le da el tono a la genealogía propuesta. Adán y Eva no están colocados ni puestos en el árbol genealógico sino encaramados como monos. El tono está marcado, además, por un gesto desafiante: "de aquí te espero". Completa el cuadro el detalle irónico del apelativo: "don Adán" y la "señora Eva"; para remate, no hay quién les quite señorío, a pesar de que nadie podría imaginarse cómo terminaron y aquí se introducen tres elementos sorpresivos, de los cuales sólo uno corresponde 
a la tradición, la tentación, ya que los otros dos constituyen un desplazamiento paródico: la perdiz reemplaza a la serpiente y estupendamente la ciruela a la manzana. El humor está conseguido a través del detalle o al por menor proporcionado por el verbo, el apelativo y el desplazamiento nominativo.

En el detalle no sólo anida el humor, ya que en él se contiene el lugar común y su trastrueque: "y puesto una placa en / la puerta en, la que podría leerse (el lugar común): soy zurdo, empuje las nubes con cuidado" (el trastocamiento); también en el detalle se produce el giro de lo real, de su lógica, a otra que funciona con parámetros distintos capaces de crear un mundo "otro" que se despliega gracias a la imaginación creadora: "Ya está bien de pamplinas con la atracción universal de los / cuerpos ideológicamente bellos, la poesía está hecha de pulsaciones eléctricas y precedentes en desorden, huellas contagiadas / por el cero absoluto de la temperatura, es decir, el teorema / de los relojes de péndulo ("Remitido a Schrödinger", pp. 12-13).

El texto es profundamente complejo a partir de la referencia de Schrödinger, Premio Nobel de Física en 1933, quien postulaba que la vida no es ajena a la ley de la termodinámica, tesis que le permite al poeta rechazar como "pamplinas" las teorías de Fourier sobre la atracción universal de los cuerpos, inspirada en la ley de gravitación de Newton.

El detalle abre aquí otra dimensión básica de la poesía de Mestre: la intertextualidad. Ella supera largamente el diálogo con otras obras literarias para proyectarse hacia las relaciones con la física, la filosofía, la astronomía, la cábala, proyección de la cual nace el carácter polifónico de esta poesía que, junto con conferirle belleza y plasticidad, exige la presencia de un lector avisado y competente.

El esfuerzo del "lector ideal" se hace más fácil cuando los detalles apuntan a experiencias cotidianas expresadas en esa lengua común a la que hacíamos referencia, pero cuando el detalle se transforma en un "lujo" del enunciado poético la dificultad de la lectura se hace gravitante.

Puedo en este nivel volver a la separación oscilante entre lengua extranjera y lengua cotidiana mediante un nuevo punto de vista más aclaratorio. Son los distintos procedimientos en el uso del detalle poético lo que las separa. En la lengua extranjera dentro de la propia lengua, el detalle funciona como un "exceso lujoso" del discurso lírico; en cambio, en la lengua de todos los días se emplea como un referente descarnado. Sin embargo, esta es una separación aparente porque es muy simple pensar que el detalle lujoso se refiere a lo que está demás, a una "sobrecarga" innecesaria del léxico poético. Si lo observamos con profundidad podemos advertir que en él se produce una hiperbolización paródica de los procedimientos "culteranos" 
que deriva en su relativización y, fundamentalmente, deriva en un mecanismo de resistencia al poder. Asimismo, el carácter referencial del detalle en la lengua cotidiana no es tal, ya que el humor y la ironía lo transforman en puerta que se abre al delirio de la escritura. Y ya puedo decirlo: escribir es delirar en la poesía de Juan Carlos Mestre, porque sólo mediante el delirio se puede alcanzar la mayor utopía: hacer desaparecer "la muerte y sus nombres":

\section{ÚLTIMAS PALABRAS}

La ley desaparece en el mundo desaparece las chozas se desploman los diamantes se licuan los labios bajan a tocar las campanas de yeso los ancianos sorben la espuma arden las órdenes los manantiales las cabezas arden con el pelo liso los enfermos abandonan la certeza el sueño las manzanas dejan de madurar no sé si me explico la primavera en una camilla un palo no hay respuesta el autobús cambia de ruta los constructores van al bautizo las prisiones desaparecen los cubos de los hospitales la muerte y sus nombres (Mestre, 2012: 468).

Este hermoso texto que nos habla del desaparecimiento y del fuego destructor, y en una imagen sorprendentemente "antipoética" de la invalidez de la primavera ("la primavera en una camilla de palo"), pareciera apuntar solamente al vacío que acecha al poeta suspendido cabeza abajo sobre él. Abismo en el que desaparece el mundo, los diamantes, los labios, mientras arden los manantiales. Pero estupendamente el desasimiento total también toca a la muerte y sus terribles nombres. La negatividad es tan profunda que termina por invertir su signo expulsando a la muerte del mundo: "desaparecen los cubos de los hospitales la muerte y sus nombres".

De la destrucción emerge la positividad de un mundo sin muerte donde la vida renovada se resiste a desaparecer, aunque esté postrada en una camilla de palo; otro signo a la resistencia a la muerte es la porfía de las manzanas que no quieren madurar, que recuerdan lejanamente a las ciruelas nerudianas que caídas a tierra "se pudren en el tiempo infinitamente verdes". Latencia de la vida que no quiere morir en "Galope muerto" de Pablo Neruda, en el texto de Mestre la muerte de la vida arrastra la muerte de la propia muerte. En este morir de la muerte se mezclan el delirio y la utopía que caracterizan la escritura de Mestre. A no olvidar, sin embargo, el dispositivo del humor y la ironía que relativizan o hacen aterrizar los delirios utópicos.

¿Qué más puedo decir de este libro con el que Mestre parece querer coronar su obra poética? Yo diría que su mismo carácter intenso y extenso 
juega a favor y en contra de él. Lo de a favor ya he intentado explicarlo, el juego en contra debe ser propuesto y entendido cuidadosamente. En primer término, hay repeticiones del texto en el sentido que se abordan ciertos ciclos que parecen estar agotados en un punto textual, pero se vuelven a retomar más adelante. Por ejemplo, los poemas construidos sobre figuras paradigmáticas de la cultura universal, aunque haya aciertos notables en esta línea.

En una palabra, a este texto le sobran algunas palabras. Con toda la admiración que he aprendido a sentir sobre la bella y fascinante poesía de Mestre, yo habría hecho un recorte y reducido el texto. No más de cien poemas, o 120, ó 110, ya que el número no es lo importante sino el evitar repeticiones, que sí las hay. Pero tal vez me equivoque y estos 298 poemas del texto sean absolutamente necesarios, imprescindibles para configurar alguna forma secreta del universo que ha vislumbrado al poeta amigo, amigo mágico "lirófolo celeste".

\section{REFERENCIAS}

Mestre, J. C. (2012). La bicicleta del panadero. Madrid: Calambur. 